\title{
Operating cash flow in commercial firms listed on the Ho Chi Minh Stock Exchange
}

\author{
Do Duc Tai \\ University of Labor and Social \\ Affairs, Vietnam \\ Email: \\ taiketoanquocte@gmail.com
}

\author{
Tran Manh Dung \\ National Economics \\ University, Vietnam \\ Email: \\ manhdung@ktpt.edu.vn
}

\author{
Nguyen Thi Xuan Hong* \\ Hanoi University of Industry, \\ Vietnam \\ Email: \\ nguyenthixuanhong@haui.edu.vn
}

\begin{abstract}
The study is conducted to scrutinize four operating cash flow indices of commercial firms listed on the Ho Chi Minh Stock Exchange (HSX). The research employs a set of aggregated data from 14 commercial firms. At the same time, the study also receives comments from experts experienced in the same field. We used both qualitative and quantitative methods. We have performed some descriptive analysis, compared to evaluate and measure four operating cash flow indices of commercial firms, including: (i) Operating cash flow/net sales; (ii) Operating cash flow/total assets, (iii) Operating cash flow/ owner's equity, and (iv) Operating cash flow/net operating profit. The results illustrate that there is a big difference in operating cash flow indices of commercial firms listed in the context of Vietnam. Foreign ownership accounts for a relatively low proportion of these firms. Based on the results, some suggestions are proposed for commercial firms in order to improve the four operating cash flow indices.
\end{abstract}

Index Terms-operating cash flow, net sales, assets, owner's equity.

\section{INTRODUCTION}

$I^{\mathrm{N}}$ N FIRMS' business activities, there is a variety of information to evaluate and analyse, such as: human resources, firm's competitiveness, indexes of profitability, growth, solvency, cash flow capacity, etc. which include operating cash flow and operating cash flow indices.

For a firm, cash flow is a bloodline that affects business activities of the firm tremendously. Therefore, assessing the cash flow capacity and operating cash flow indices are always of interest to business owners and investors. Cash flow indexes are employed to measure the profitability from business activities and display the efficiency of cash flow, thereby helping business managers devise and perfect more profitable decisions for the sake of the firm in the future.

'Investors' reactions are regarded to be passive in the changes of the stock market because they, to some extent, do not have enough data and information in making sound economic decisions. So, having relevant financial information including information of cash flow - is too important and necessary to help individual investors be more confident and comfortable when making investment decisions.

There are some studies on the world and domestic about cash flows, such as, "[11] used 475 firm-year observations during the period 2006-2010 to evaluate the relative and incremental information content of earnings and operating cash flows of traded companies. The findings illustrated that earnings are more employed than operating cash flows in explaining stock returns. According to [7], cash flow has both positive and negative impacts on the stock returns and the health of companies; the abundant amount of cash enables firms to immediately have good investment opportunities when the cost of external finance is too high or be more proactive when facing financial shocks."'[8] chose the Association of Southeast Asian Nations (ASEAN) to investigate different roles of cash flows in evaluating the return on investment. They suggested that enterprises should manage cash flow in a prudent manner when consider the firm value from the shareholder's perspective. Cash returns become an important performance indicator for the company, while higher cash component over reported earnings is preferred. However, these studies have not much investigated operating cash flow indices of firms.

Commercial firms have an important role in regulating goods supply and demand that is providing both manufacturers and consumers information about one another. As a result, goods are better distributed and manufacturers can make sure their production is effective and meeting customer's needs. With activities such as commercial promotions or trade promotions, etc. commercial firms help manufacturers to promote products, engage customers and bring the products to customers' awareness. Thenceforth, details of the products can be directly provided to customers through sales staff, catalogues, etc. Commercial firms in general, and commercial firms listed on the HSX in particular have used a variety of management tools, including cash-flow related methods in order to ensure the accomplishments of objectives and strategies, etc. However, the operating cash flow indices of commercial firms have not been fully utilized. In addition, not many researchers are interested in the topic of operating cash flow indices.

This research analyses, evaluates and measures the operating cash flow indices in commercial firms, including (i) Operating cash flow/net sales (OCFNS); (ii) Operating cash flow/total assets (OCFTA), (iii) Operating cash flow/owner's equity (OCFOE), (iv) Operating cash flow/net operating profit (OCFNOP).

\section{Literature Review}

\section{A. Operating cash flow}

There are some studies on operating cash flow, such as [5] studied in the United States, [6] studied in Australia. In the context of Vietnam, [1] looked into forecasting operating cash flow of enterprises listed on the HSX. The role of cash 
flow to an enterprise is as important as a blood flow in the human body [2].

Operating cash flow (OCF) is the money inflow and outflow related to the income and expenses of the business, which occurs regularly in the production and business activities. Operating cash flow reflects cash inflows and outflows related to firm activities within a period, including cash flows related to securities held for business purposes [10].

Operating cash flow inflows, include (i) Sales revenue, service provisions and other revenues. Other revenues here include royalties, fees, commissions and other sources of revenue such as sales of business securities; (ii) Other revenues from business activities include: proceeds due to tax refund, advance recovery, recovery of funds, compensation revenues and other revenues not covered by investment and financial activities cash flow [10].

Operating cash flow outflows, include (i), Payments to suppliers of goods and services, including purchases of trading securities; (ii) Wages; (iii) Loan interest payments; (iv), Corporate income tax; (v) Other expenses for business activities such as insurance premiums, advances, funds, potential compensation due to the firm's breach of economic contracts and other expenses not included in the investment cash flow and financial cash flow [10].

\section{The role of operating cash-flow}

Operating cash-flow is the most important in a cash flow statement because it shows the ability of the business to generate cash from within the business activities to repay debt, pay dividend and increase investment.

In addition, the information derived from operating cashflow is an important foundation for the planning of cash flows for future periods.

Interviewed experts said that OCF is one of the better indicators of a firm's profitability than earnings because a firm may report positive earnings figures on its financial statements while it still is unable to repay the loan. Cash flow is what helps firms pay their bills and due debts. By making use of OCF, investors can examine firms' income conditions. If a firm reports earnings data at a record high but has a negative inflow, it means that the business is having problems with cash flow, and the firm is polishing its image.

\section{Determination of operating cash flow}

Based on the direct method, net Operating Cash Flow is calculated by subtracting operating expenses from revenues; those revenues and expenditures are reported on the basis of the capital account in cash and counterpart accounts [10].

Under the indirect approach, the operating cash inflows and outflows are first measured by adjusting the profit before income tax (IT) of the business by excluding non-cash items, inventories change within the period, receivables and payables from operating activities, and amounts which are a result of investing cash flows.

\section{B. Operating Cash Flow/Net Sales}

This ratio implies the difference between the net operating cash flow and the revenue of the firm. This ratio can be used to measure a firm's capacity to generate income from revenue.

When the company's revenue increase is not accompanied by the growth in operating cash flow, there is a risk.

\section{Operating Cash Flow/total assets}

The ratio of operating cash flow to total assets is a financial indicator reflecting the relationship between a firm's OCF and its total resources.

This ratio is used to evaluate the conversion efficiency from assets that generate cash flows for businesses.

Operating cash flow to total assets implies the difference between operating cash flow and total assets. The assets of a firm are made up of borrowed capital and equity. Investors should also pay attention to the interest rates that firms are responsible to pay on debt. Besides, this ratio increases the credibility of a firm's financial power. To fully utilise, investors may evaluate volatility trends in the most recent 3 - 5 years and make comparisons with other firms in the industry.

\section{Operating Cash Flow/Owner's equity}

This ratio indicates the amount of operating cash inflow for every unit of equity.

This index will answer the question: For every unit of equity spent, how much money will be generated from operating activities.

The higher the ratio is, the more effectively the firm is using the capital from shareholders, which indicates the firm can balance between shareholders' capitals and borrowed capitals to efficiently exploit its competitive edge during capital mobilization and expansion stage. Therefore, investors will be attracted to stocks of firms with this ratio high.

\section{E. Operating Cash Flow/Operating profit}

This ratio is one of several indicators that help managers measure the capacity to generate money from business activities in relation to profits. This ratio shows how much firms receive for each unit of profit earned. Consequently, this ratio can help business managers build and perfect the direction along with appropriate strategies and investment decisions for the coming time of the firm.

\section{Research Methodology}

\section{A. Context and sample}

Currently in Vietnam, there are 14 commercial firms listed on the HSX (Table 1). Commercial firms listed on the HSX were listed at different times, have different numbers of outstanding shares, and different current equity.

$$
\text { TABLE } 1
$$

Listed Commercial Firms on the HSX

\begin{tabular}{|c|c|c|c|c|c|c|}
\hline No & tock code & Name's firm & $\begin{array}{c}\text { No. of shares } \\
\text { outstanding }\end{array}$ & ${ }^{s}$ transaction & $\begin{array}{c}\text { Owner's } \\
\text { equity } \\
\text { (million } \\
\text { VND) }\end{array}$ & $\begin{array}{c}\text { Foreign } \\
\text { Ownership } \\
(\%)\end{array}$ \\
\hline 1 & BTT & $\begin{array}{l}\text { Ben Thanh } \\
\text { Trading and } \\
\text { Service Co. }\end{array}$ & $5,312,920$ & 2007 & 363,957 & 4.67 \\
\hline 2 & $\mathrm{CCI}$ & $\begin{array}{l}\text { CuChi commercial } \\
\text { and industrial } \\
\text { developing } \\
\text { investment Co. }\end{array}$ & $17,541,105$ & 2010 & 275,406 & 2.43 \\
\hline 3 & CMV & $\begin{array}{l}\text { Ca Mau Trading } \\
\text { Joint Stock Co. }\end{array}$ & $18,155,868$ & 2010 & 197,802 & 0.23 \\
\hline 4 & DGW & Digiworld Co. & $44,200,278$ & 2015 & $1,158,586$ & 24.98 \\
\hline 5 & GIL & $\begin{array}{l}\text { BinhThanh import } \\
\text { export production } \\
\text { and trade Co. }\end{array}$ & $36,000,000$ & 2002 & $1,289,988$ & 5.32 \\
\hline 6 & HDC & $\begin{array}{c}\text { Ba Ria - Vung Tau } \\
\text { House } \\
\text { Development Co. }\end{array}$ & $83,143,874$ & 2007 & $1,142,139$ & 2.51 \\
\hline 7 & MWG & Mobile World & $475,271,464$ & 2014 & $15,481,690$ & 49.01 \\
\hline
\end{tabular}




\begin{tabular}{|c|c|c|c|c|c|c|}
\hline No & tock code & Name's firm & $\begin{array}{c}\text { No. of shares } \\
\text { outstanding }\end{array} \mid$ & $\begin{array}{c}\text { transaction } \\
\text { date }\end{array}$ & $\begin{array}{c}\text { Owner's } \\
\text { equity } \\
\text { (million } \\
\text { VND) }\end{array}$ & $\begin{array}{c}\text { Foreign } \\
\text { Ownership } \\
(\%)\end{array}$ \\
\hline & & Investment Co. & & & & \\
\hline 8 & PET & $\begin{array}{c}\text { Petrovietnam } \\
\text { General Services } \\
\text { Co. }\end{array}$ & $83,570,524$ & 2007 & $1,663,166$ & 5.65 \\
\hline 9 & PIT & $\begin{array}{c}\text { Petrolimex } \\
\text { International } \\
\text { Trading Co. } \\
\end{array}$ & $14,210,225$ & 2008 & 120,624 & 0.8 \\
\hline 10 & PNJ & $\begin{array}{l}\text { Phu Nhuan } \\
\text { Jewelry Co. }\end{array}$ & $227,366,56$ & 2009 & $5,241,862$ & 48.34 \\
\hline 11 & SMA & $\begin{array}{l}\text { Sai Gon Machinery } \\
\text { Spare Parts Co. }\end{array}$ & $20,352,836$ & 2010 & 166,550 & 0.04 \\
\hline 12 & SMC & \begin{tabular}{|c|} 
SMC Trading \\
Investment Joint \\
Stock Co., \\
\end{tabular} & $60,922,941$ & 2006 & $1,584,291$ & 22.17 \\
\hline 13 & SVC & $\begin{array}{c}\text { Saigon General } \\
\text { Service Co. }\end{array}$ & $33,300,466$ & 2009 & $1,743,131$ & 1.92 \\
\hline 14 & TNA & $\begin{array}{l}\text { Thien Nam } \\
\text { Trading Import } \\
\text { Export Co. }\end{array}$ & $39,385,930$ & 2005 & 565,710 & 3.77 \\
\hline
\end{tabular}

Along with the economic development of the country, joint stock commercial firms listed on the HSX have recently shown strong development, and significantly contributed to the development of the country.

Most of the commercial firms listed on the HSX have wide business areas scattered throughout the country and even abroad. For the sake of business, these firms usually have to open branches and set up stores in different regions and localities. Firms may choose to operate in various types such as commercial, service, real estate, etc.

Commercial firms listed on HSX may choose to operate in various types of businesses; goods produced can be sold in wholesales, retails, agency, services, etc.

This study employs a balance sheet whose data is categorized according to objects and time. Secondary data were collected from audited financial reports of 14 commercial firms listed in HSX as of the end of the accounting year 2020 from the [12]. The study involved 14 firms over five years, with a total of 56 observation variables. All 56 observations are included in the analysis through synthesis and data cleaning.

\section{B. Research Approach}

This study employs qualitative methods with secondary data collection and expert interviews. Experts consulted include two experienced lecturers in the field of finance from the National Economics University and two chief accountants of commercial firms. The interview revolves around the assessment of four OCF ratios as mentioned within the scope of this study. Experts will make analysis of the status of commercial firms' OCF ratios and provide their professional opinions on the suitability anticipated from those operating cash flow ratios and the relevance between operating cash flow ratios and firm's production, business activities and other aspects. The study also employs quantitative methods by calculating and comparing OCF with the help of descriptive statistics and correlation analysis by Excel and Stata 13.

\section{Results \& Discussion}

\section{A. Ratio of operating cash flow/net sales}

Table 2 and 3 reveal that there are three firms whose proportion of operating cash flow/net sales is higher than $10 \%$. Two firms that have a high ratio of operating cash flow to net
TABLE 2

THE RATIO OF OPERATING CASH FLOW TO NET SALES OF LISTED FIRMS Unit: \%

\begin{tabular}{|c|c|c|c|c|c|}
\hline Code & $\mathbf{2 0 1 7}$ & $\mathbf{2 0 1 8}$ & $\mathbf{2 0 1 9}$ & $\mathbf{2 0 2 0}$ & Average \\
\hline BTT & 20.64 & 29.07 & 13.14 & 7.08 & 17.48 \\
\hline CCI & 12.15 & 6.09 & 3.26 & 5.59 & 6.77 \\
\hline CMV & 3.62 & 0.08 & -0.94 & 1.09 & 0.96 \\
\hline DGW & 0.45 & -2.49 & 12.25 & 7.26 & 4.37 \\
\hline GIL & -6.08 & -2.12 & 3.38 & 6.59 & 0.44 \\
\hline HDC & 32.90 & -27.76 & 9.92 & 33.05 & 12.03 \\
\hline MWG & 4.02 & 2.61 & -1.26 & 9.94 & 3.83 \\
\hline PET & 0.04 & 1.78 & 3.12 & -0.30 & 1.16 \\
\hline PIT & 3.93 & 9.14 & 7.42 & -6.95 & 3.39 \\
\hline PNJ & 1.00 & -2.07 & -3.89 & 8.55 & 0.90 \\
\hline SMA & 8.26 & 16.86 & 24.82 & 44.53 & 23.62 \\
\hline SMC & 4.97 & -0.26 & 2.75 & 2.83 & 2.57 \\
\hline SVC & 4.28 & -1.03 & -0.23 & 5.77 & 2.20 \\
\hline TNA & -1.40 & -2.94 & 0.36 & -4.73 & -2.18 \\
\hline
\end{tabular}

sales are firms with stock codes of SMA and BTT; otherwise, the firm with stock symbol of TNA possess the smallest operating cash flow.

TABLE 3

The Ratio Of Operating Cash Flow To Net Sales Of Firms

\begin{tabular}{|c|c|c|c|c|c|}
\hline Description & $\mathbf{2 0 1 7}$ & $\mathbf{2 0 1 8}$ & $\mathbf{2 0 1 9}$ & $\mathbf{2 0 2 0}$ & $\begin{array}{c}\text { Average } \\
\mathbf{2 0 1 7 - 2 0 2 0}\end{array}$ \\
\hline $\begin{array}{c}\text { Operating cash } \\
\text { flow/net sales }\end{array}$ & 6.34 & 1.93 & 5.29 & 8.59 & 5.54 \\
\hline
\end{tabular}

During the period from 2017 to 2020, the ratio of operating cash flow to average net sales of commercial firms is $5.54 \%$, meaning that operating cash flow constitutes a low proportion in net sales.

The financial experts supposed that changes in terms of sales as well as debt policy can be reflected in these ratios. It is also acclaimed that the higher the ratio is the better. However, the ratio reported within a firm should be different from the industry's average. That is why, investors need to know the kind of this ratio for detecting significant deviations from the firm's average cash flow/revenue, as well as compare this ratio of other firms within the industry. In addition, investors also need to observe fluctuation of revenues in correlation

TABLE 4

The Ratio Of Operating Cash Flow To Assets Of Firms

Unit: \%

\begin{tabular}{|c|c|c|c|c|c|}
\hline Code & $\mathbf{2 0 1 7}$ & $\mathbf{2 0 1 8}$ & $\mathbf{2 0 1 9}$ & $\mathbf{2 0 2 0}$ & Average \\
\hline BTT & 16.09 & 20.96 & 7.83 & 2.39 & 11.82 \\
\hline CCI & 5.94 & 3.53 & 1.81 & 2.34 & 3.41 \\
\hline CMV & 23.19 & 0.55 & -6.09 & 7.58 & 6.31 \\
\hline DGW & -14.58 & -5.65 & 11.92 & 26.93 & 4.66 \\
\hline GIL & 0.66 & -3.04 & 16.38 & 9.26 & 5.82 \\
\hline HDC & 8.98 & -12.12 & 3.32 & 8.32 & 2.13 \\
\hline MWG & 11.67 & 8.04 & -3.08 & 23.45 & 10.02 \\
\hline PET & 0.07 & 3.55 & 6.28 & -0.64 & 2.32 \\
\hline PIT & 13.65 & 35.38 & 22.78 & -11.50 & 15.08 \\
\hline PNJ & 2.40 & -4.69 & -7.68 & 17.65 & 1.92 \\
\hline SMA & 6.49 & 13.59 & 6.53 & 7.53 & 8.54 \\
\hline SMC & 12.43 & -0.85 & 9.12 & 6.62 & 6.83 \\
\hline SVC & 16.29 & -3.50 & -0.88 & 21.78 & 8.42 \\
\hline TNA & -4.30 & -6.60 & 0.95 & -11.63 & -5.40 \\
\hline
\end{tabular}


TABLE 5

The Ratio Of Operating Cash Flow To Total Assets Of Listed Firms

Unit: \%

\begin{tabular}{|c|c|c|c|c|c|}
\hline Ratio & $\mathbf{2 0 1 7}$ & $\mathbf{2 0 1 8}$ & $\mathbf{2 0 1 9}$ & $\mathbf{2 0 2 0}$ & $\begin{array}{c}\text { Average } \\
\mathbf{2 0 1 7 - 2 0 2 0}\end{array}$ \\
\hline $\begin{array}{c}\text { Operating cash } \\
\text { flow/total assets }\end{array}$ & 7.07 & 3.51 & 4.94 & 7.86 & 5.85 \\
\hline
\end{tabular}

with cash-flow and assess their relative increase with one another.

\section{B. Operating cash flow/total assets}

Table 4 and 5 demonstrate that commercial firms' operating cash flow proportion in total assets has a noticeable difference. While the firm with the stock code of PIT has the highest operating cash flow proportion in total assets (i.e. $15.08 \%$ ), this proportion of firm with the stock code of TNA is $-5.40 \%$. For each firm, the ratio of operating cash flow to total assets also changes sharply during the period from 2017 to 2020 .

The ratio of operating cash flow to average total assets of commercial firms listed tends to increase from 2018 to 2020 .

\section{Operating cash flow/owner's equity}

Table 6 and 7 illustrate that during the period 2017 2020, three listed firms listed with stock codes of PNJ, PET, $\mathrm{CCI}$ have the low ratios. However, some firms have a fairly high ratio such as firms with stock symbols of PIT and MWG.

TABLE 6

The Ratio Of Operating Cash Flow To Owner’s Equity Of Listed Firms

Unit: \%

\begin{tabular}{|c|c|c|c|c|c|}
\hline Code & $\mathbf{2 0 1 7}$ & $\mathbf{2 0 1 8}$ & $\mathbf{2 0 1 9}$ & $\mathbf{2 0 2 0}$ & Average \\
\hline BTT & 23.73 & 30.79 & 11.46 & 3.25 & 17.31 \\
\hline CCI & 15.15 & 8.97 & 4.60 & 5.89 & 8.65 \\
\hline CMV & 89.29 & 2.18 & -24.54 & 23.20 & 22.53 \\
\hline DGW & -33.70 & -16.39 & 31.00 & 71.33 & 13.06 \\
\hline GIL & 1.75 & -7.90 & 37.18 & 19.45 & 12.62 \\
\hline HDC & 18.84 & -24.73 & 7.06 & 24.28 & 6.36 \\
\hline MWG & 45.08 & 25.17 & -10.59 & 69.71 & 32.34 \\
\hline PET & 0.25 & 12.17 & 19.03 & -2.44 & 7.25 \\
\hline PIT & 56.59 & 123.28 & 56.94 & -31.75 & 51.27 \\
\hline PNJ & 3.61 & -8.07 & -14.44 & 28.56 & 2.42 \\
\hline SMA & 17.66 & 32.41 & 14.35 & 19.70 & 21.03 \\
\hline SMC & 51.95 & -3.32 & 34.74 & 28.07 & 27.86 \\
\hline SVC & 46.13 & -9.93 & -2.55 & 53.24 & 21.72 \\
\hline TNA & -14.06 & -26.72 & 2.97 & -43.78 & -20.40 \\
\hline
\end{tabular}

TABLE 7

The Ratio Of Operating Cash Flow To Owner's Equity Of Listed Firms

Unit: \%

\begin{tabular}{|c|c|c|c|c|c|}
\hline Ratio & $\mathbf{2 0 1 7}$ & $\mathbf{2 0 1 8}$ & $\mathbf{2 0 1 9}$ & $\mathbf{2 0 2 0}$ & $\begin{array}{c}\text { Average } \\
\mathbf{2 0 1 7 - 2 0 2 0}\end{array}$ \\
\hline $\begin{array}{c}\text { Operating cash } \\
\text { flow/owner's equity }\end{array}$ & 23.02 & 9.85 & 11.94 & 19.19 & 16.00 \\
\hline \multicolumn{5}{c}{ Source: Authors' compilations }
\end{tabular}

The ratio of operating cash flow to average owner's equity over the years of commercial firms listed on HSX is $16.00 \%$, which is considered average.
TABLE 8

The Ratio Of Operating Cash Flow To Net Operating Profit Of Listed Firms

Unit: \%

\begin{tabular}{|c|c|c|c|c|c|}
\hline $\begin{array}{c}\text { Stock } \\
\text { code }\end{array}$ & $\mathbf{2 0 1 7}$ & $\mathbf{2 0 1 8}$ & $\mathbf{2 0 1 9}$ & $\mathbf{2 0 2 0}$ & Average \\
\hline BTT & 152.64 & 166.31 & 64.09 & 80.36 & 115.85 \\
\hline CCI & 117.25 & 63.21 & 33.67 & 42.69 & 64.21 \\
\hline CMV & $-1,346.39$ & 210.98 & $2,698.46$ & $1,069.15$ & -567.71 \\
\hline DGW & -248.66 & -91.46 & 136.57 & 248.94 & 11.35 \\
\hline GIL & 5.60 & -27.40 & 158.74 & 63.38 & 50.08 \\
\hline HDC & 139.43 & -165.46 & 45.86 & 95.75 & 28.90 \\
\hline MWG & 95.29 & 59.91 & -25.54 & 199.40 & 82.27 \\
\hline PET & 2.07 & 113.87 & 311.45 & -20.39 & 101.75 \\
\hline PIT & -169.27 & -442.90 & -496.89 & $-1,857.30$ & -741.59 \\
\hline PNJ & 12.15 & -25.10 & -43.89 & 110.95 & 13.53 \\
\hline SMA & 70.10 & 271.08 & 181.98 & 274.50 & 199.42 \\
\hline SMC & 187.82 & -21.11 & 328.89 & 120.56 & 154.04 \\
\hline SVC & $-6,290.13$ & -58.79 & -31.14 & 717.59 & $-1,415.62$ \\
\hline TNA & -46.09 & -240.02 & 10.20 & -470.08 & -186.50 \\
\hline
\end{tabular}

Source: Authors' compilations

TABLE 9

The Ratio Of Operating Cash Flow To Net Operating Profit Of Listed Firms

Unit: \%

\begin{tabular}{|c|c|c|c|c|c|}
\hline Ratio & $\mathbf{2 0 1 7}$ & $\mathbf{2 0 1 8}$ & $\mathbf{2 0 1 9}$ & $\mathbf{2 0 2 0}$ & $\begin{array}{c}\text { Average } \\
\mathbf{2 0 1 7 - 2 0 2 0}\end{array}$ \\
\hline $\begin{array}{c}\text { Operating cash } \\
\text { flow/net } \\
\text { operating } \\
\text { profit }\end{array}$ & -522.73 & -13.35 & 51.85 & -30.28 & -128.63 \\
\hline
\end{tabular}

Source: Authors' compilations

\section{Operating cash flow/net operating profit}

Table 8 and Table 9 present that commercial firms' ratio of operating cash flow to net operating profit is uneven. This ratio of firms with the stock code of SMA is extremely high, $199.42 \%$. Meanwhile, the ratio of firm with stock code of DGW is low, only $11.35 \%$. However, the mean ratio of listed commercial firms in 2017 - 2020 is $-128.63 \%$.

The financial specialists stated that the higher this index value is the better since as it shows that the firm is developing. In addition, firm managers should compare this ratio with the industry's average in order to assess their firms' positions in comparison with other businesses in the industry. Financial experts also believe that tracking this ratio chronologically will assist investors to easily detect the firm's deficiencies.

\section{E. Descriptive statistics}

Data in Table 10 reveal that each operating cash flow indexes are calculated by 56 observations. Basic numbers of mean, max, min, standard deviation (SD), variance, skewness coefficient of variation, the sum of variables, range, coefficient of variation, coefficient of variation of each observed variable (CV) have been tabulated; and these indices accurately reflect the current states of operating cash flow indices of listed commercial firms.

Owner's equity (OE): The dummy variable is 1 if the firm has 1,000,000 million VND or more of owner's equity; is 0 for other cases. 
TABLE 10

General and Detailed Descriptive Statistics

\begin{tabular}{|l|c|c|c|c|c|}
\hline \multicolumn{6}{|l|}{ General descriptive statistics } \\
\hline Variables & Obs & Mean & Std. Dev. & Min & Max \\
\hline OCFNS & 56 & .0553821 & .1118202 & -.2776 & .4453 \\
\hline OCFTA & 56 & .0584643 & .1060281 & -.1458 & .3538 \\
\hline OCFOE & 56 & .1600179 & .3137895 & -.4378 & 1.2328 \\
\hline OCFNOP & 56 & -.6173429 & 10.01823 & -62.9013 & 26.9846 \\
\hline
\end{tabular}

Detailed descriptive statistics

\begin{tabular}{|l|c|c|c|c|}
\hline \multicolumn{1}{|c|}{ stats } & OCFNS & OCFTA & OCFOE & OCFNOP \\
\hline $\mathrm{N}$ & 56 & 56 & 56 & 56 \\
\hline sum & 3.1014 & 3.274 & 8.961 & -34.5712 \\
\hline range & .7229 & .4996 & 1.6706 & 89.8859 \\
\hline variance & .0125038 & .0112419 & .0984638 & 100.3649 \\
\hline $\mathrm{cv}$ & 2.019065 & 1.813553 & 1.960965 & -16.22798 \\
\hline skewness & 1.04816 & .4052229 & .8439452 & -4.131307 \\
\hline kurtosis & 6.263296 & 2.960111 & 4.355129 & 29.00523 \\
\hline p50 & .0332 & .0611 & .1326 & .6156 \\
\hline
\end{tabular}

Comparison of operating cash flow indices of listed firms with owner's equity over 1,000,000 million VND and the remaining firms

Table 11 shows that there were 24 firms (6 firms in the 2017-2020 period) with $1,000,000$ million VND or more rate of owner's equity.

OCFNS: firms with owner's equity of $1,000,000$ million VND or more have a smaller OCFNS than the rest. The difference on OCFNS between firms with 1,000,000 million VND or more owner's equity and the rest is not statistically significant ( $\mathrm{p}$-value is 0.42 , higher than 0.05 ; difference value 0.0244

OCFTA: firms with owner's equity of $1,000,000$ million VND or more have a larger OCFTA than the rest. The difference on OCFTA between firms with 1,000,000 million VND or more owner's equity and the rest is not statistically significant ( $p$-value is $0.52>0.05$; difference value 0.0186

OCFOE: firms with owner's equity of 1,000,000 million VND or more have a larger OCFOE than the rest. The difference on OCFOE between firms with 1,000,000 million VND or more owner's equity and the rest is not statistically significant (p-value is $0.37>0.05$ ).

OCFNOP: firms with owner's equity of $1,000,000$ million VND or more have a smaller OCFNOP than the rest. The difference on OCFNOP between firms with 1,000,000 million VND or more owner's equity and the rest is not statistically significant ( $p$-value is 0.53 , higher than 0.05 ; difference value 1.6920 [4].

\section{Conclusion}

This study has evaluated four OCF ratios of commercial firms listed on HSX with mixed research methods. With the contemporary status of those firms, it was depicted that firms with more stable and high OCF ratios received a great deal of interest from investors and their firms were operating decently.

Firms with poor operating cash flow ratios need to take strategies to improve the OCF ratios such as increase revenue (expand market, diversify sales policies, etc.), reduce costs (control costs, allocate costs appropriately, avoid excessive costs). In addition, businesses also need to modify terms of sales or diversify debt policies for each customer group or individual in order to improve these ratios.

According to [9], cash flow, overconfidence and investment have a close relationship. They affirmed that CEOs with overconfidence, large free cash flow and unaffected firms tend to invest more. In contrast, the cash flow is to some extent limited or not big enough to invest, CEOs tend to invest less instead of raising capital by issuing shares or CEOs show that the issuance of shares will be information that makes the market underestimation [9]. Cash flow from operations, along with earnings, is an important asset of the firm value. The use of cash flow indicators has always been underlined by the accounting community [3].

\section{REFERENCES}

[1] Anh, N. H. (2013). Forecast operating cash flow of enterprises listed on the Ho Chi Minh City Stock Exchange. Journal of Economic and Development, 10/2013, 20-27. [Vietnamese]

[2] Anh, N. H., and Hieu, N. T. (2015).Using historical accounting profit and cash flow information to forecast operating cash flow of nonfinancial firms listed on the Ho Chi Minh Stock Exchange. Journal of Economy of Asia - Pacific, 458, 78-80. [Vietnamese]

[3] Asgari, L., Salehi, M., and Mohammadi, A. (2014). Incremental Information Content of Cash Flow and Earnings in the Iranian Capital Market. Journal of Industrial Distribution and Business, 5-1, 5-9.

[4] Bryman, A., and Cramer, D. (2001). Quantitative data analysis with SPSS release 10 for Windows: A guide for social scientists ( $1^{\text {st }} \mathrm{Ed}$.). https://doi.org/10.4324/9780203471548

[5] Greenberg, R., Johnson, G., \& Ramesh. K. (1986). Earnings versus Cash Flow as a Predictor of Future Cash Flow Measures. Journal of Accounting, Auditing \& Finance, 1(4), 266-277.

[6] Habib, A. (2010). Prediction of operating cash flows: further evidence from Australia. Australian Accounting Review, 20(2), 134.

[7] Hau, L. L., and Vy, Q. N. T. (2017). The influences of free cash flows on firm performance: Evidence from listed firms on the Ho Chi Minh stock Exchange. The journal of Banking Technology, 137, 72-84. [Vietnamese]

[8] Lau, W. T., and Mahat, F. B. (2019). Robustness of Cash Flow Value: Investment in ASEAN. Journal of Asian Finance, Economics and Business, 6(2), 247-255.

[9] Malmendier, U., and Tate, G. (2005). CEO overconfidence and corporate investment. The Journal of Finance, 60(6), 2661-2700.

[10] Ministry of Finance (2014), Circular No. 200/2014/TT-BTC on guiding the accounting system of firms, Finance Publishing House.

[11] Pouraghajan, A., Emamgholipour, M., Niazi, F., and Samakosh, A. (2012). Information content of earnings and operating cash flows: evidence from the Tehran Stock Exchange. International Journal of Economics and Finance, 4, 41-51.

[12] Website: cophieu68.vn; finance.vietstock.vn 
TABLE 11

Comparison Of Operating Cash Flow Indices Among Firms With Owner's Equity Of Over 1,000,000 Million Vnd Or More And The Remaining Firms

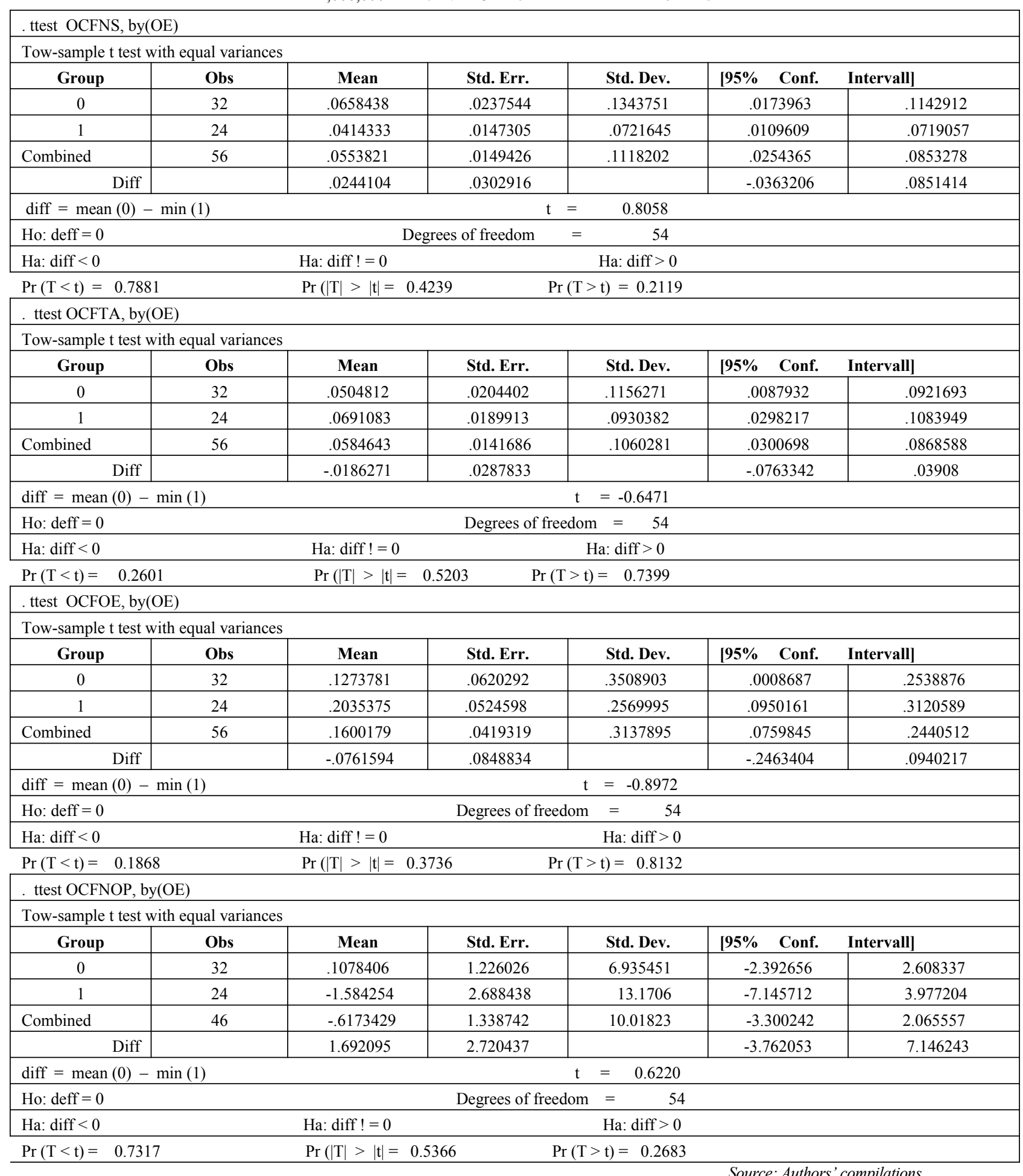

